Original Article

\title{
FORMULATION AND DEVELOPMENT OF PRONIOSOMAL GEL FOR TOPICAL DELIVERY OF AMPHOTERICIN B
}

\author{
REESHA PARVEZ BAIG'* ${ }^{*}$, MOHAMMAD WAIS ${ }^{1}$
}

1Department of Pharmaceutics, H. K. College of Pharmacy, Relief Road, Pratiksha Nagar, Oshiwara, Jogeshwari West, Mumbai 400102, India

Email: reeshabaig18@gmail.com

Received: 05 Sep 2021, Revised and Accepted: 22 Nov 2021

\section{ABSTRACT}

Objective: The present research work of Amphotericin B Proniosomal gel focuses on improving patient compliance by reducing the side effects of conventional intravenous injections and minimizing the problem of physical stability and to localize drug at site of action.

Methods: Proniosomal gels are prepared by coacervation phase separation technique using different concentration of non-ionic surfactants (Span and Tween) for uniform vesicle formation, lecithin as permeation enhancer/membrane stabilizer and cholesterol as a vesicle cement providing prolonged release. Prepared gels were evaluated for their viscosity, $\mathrm{pH}$, spreadability, entrapment efficiency, drug content uniformity, extrudability, in vitro drug release, permeability and stability studies.

Results: Among the nine formulations, F2 (containing $10 \mathrm{mg}$ drug, $250 \mathrm{mg}$ Span 60, 50 mg Soya lecithin) was found to be promising. Fourier Transform infra-red (FT-IR) spectra studies represented no interaction and physicochemical characteristics were found within the limits. The percentages of drug content and entrapment efficiency were determined to be $95.16 \% \pm 0.40$ and $94.20 \% \pm 0.20$, respectively. In vitro drug release was about $95.72 \% \pm 0.30$.

Conclusion: Proniosomal gel could constitute a promising approach for topical delivery of Amphotericin B by encapsulating it in non-ionic surfactant to provide patient compliance with cutaneous fungal infection, which was found to be safe, tolerable and efficacious.

Keywords: Amphotericin B, Proniosomal gel, Cholesterol, Carbopol, Topical, Fungal infection

(C) 2022 The Authors. Published by Innovare Academic Sciences Pvt Ltd. This is an open access article under the CC BY license (https://creativecommons.org/licenses/by/4.0/) DOI: https://dx.doi.org/10.22159/ijpps.2022v14i1.43237. Journal homepage: https://innovareacademics.in/journals/index.php/ijpps.

\section{INTRODUCTION}

Although drugs for oral and intravenous administration can be commonly used to treat skin conditions, they can also cause gastrointestinal irritation and minimise the effects of first pass metabolism. An alternative route is the use of vesicular drug encapsulation methods that include liposomes, niosomes, proniosomes, etc., which encapsulate the drug moiety in non-ionic surfactant vesicles. These are mainly used for achieving controlled release and increasing the retention time of the drug in the body and avoiding systemic absorption [1]. Formalized paraphraseIn vesicular drug delivery systems, lipid vesicles encapsulate the drug, which enters the cell membrane and, thus, enhances the bioavailability and disposition of the drug. They broadly include liposomes and niosomes [2]

Proniosomes are much more advanced than liposomes and niosomes, which is a provesicular carrier that showcasts both an improvisation in their physicochemical properties like prolonged stability, easy transportation, distribution and storage and also of pharmacological properties like prolonged existence in the systemic circulation, controlled release of the drug, augmented penetration to target organs via different routes of administration and reduced toxicity. These vesicles can encapsulate both hydrophobic and hydrophilic drugs, thus acting as a promising candidate for drug delivery [4]. Formal paraphraseNon-ionic surfactants are used in the formation of vesicles because of their benefits with respect to stability, maintaining physiological $\mathrm{pH}$, compatibility, and toxicity [5]. Formal paraphraseCholesterol forms a bilayered vesicle and also increases the stability of the prepared vesicles. Cholesterol subsides the ability of the surfactant to form aggregates and eventually provides greater stability to the lipid bilayer [6]. Formalized paraphraseSoya lecithin acts: (a) as a permeation enhancer; (b) increases drug entrapment; (c) due to an increase in lipophilicity, it changes into smaller sizes and results in a reduction of vesicle size; and (d) avoids the leakage of drug [7]. Formalized paraphrase Amphotericin B is an antifungal polyene antibiotic that is commonly used intravenously to treat visceral leishmaniasis. However, it is not always considered as an effective treatment for cutaneous leishmaniasis (CL) based on the infecting species [8]. Formalized paraphraselt opens the Leishmania membrane and activates its ion channels and aqueous pores by binding to ergosterol, which makes the bilayer thinner and increases permeability as well as loss of intracellular compounds, resulting in lysis and parasite death [9]. Amphotericin B intravenous injections cause severe toxicity, particularly nephrotoxicity in the case of conventional Amp B [10]. Hence, the current work deals with the formulation and characterization of topical proniosomal gel using cholesterol, soya lecithin and non-ionic surfactants as prime excipients.

\section{MATERIALS AND METHODS}

\section{Materials}

Amphotericin B was a generous gift sample from Piramal Pharma Ltd, Navi Mumbai, India. Cholesterol, Span $(40,60,80)$, Tween $(20$, 60,80), Phosphate Buffer Saline, Ethanol, Methanol, Carbopol 934, Methyl paraben, Triethanolamine were procured from Vishal Chemicals and were of an analytical and pharmacopeial grade.

\section{Methods}

Preformulation studies

\section{Determination of melting point of the drug}

The melting point of Amphotericin B was determined by using capillary tube method using a melting point apparatus.

\section{Fourier transform infrared spectroscopy (FT-IR) studies}

Compatibility of Amphotericin B with excipients was confirmed by FTIR studies. The FTIR study was conducted using potassium 
bromide (KBr) disc (pellet) method. FT-IR (IR Affinity S1, Shimadzu, Kyoto, Japan) was used to analyze pure drug Amphotericin B, Cholesterol, Soya lecithin, non-ionic surfactants (Span 40, Span 60, Span 80), carbopol, and their physical mixture in the same amount.

\section{Differential scanning calorimetry (DSC) studies}

The Differential Scanning Calorimetry (DSC) thermogram of Amp B drug was analyzed using Differential Scanning Calorimetry equipped with a computerized data station. The sample was weighed and heated in a closed pierced aluminium pan at a heating rate of 10 ${ }^{\circ} \mathrm{C} /$ min between $30{ }^{\circ} \mathrm{C}$ and $300{ }^{\circ} \mathrm{C}$ with a nitrogen flow rate of 25 $\mathrm{ml} / \mathrm{min}$. It illustrates the interaction of various materials at various temperatures. It also allows studying the possible degradation pathways of the materials. It gives an idea of the physical and chemical interactions between the drugs.

\section{Determination of absorption maximum ( $\lambda$ max) of the drug}

A stock solution of the drug was prepared using phosphate buffer solution (PBS) at pH 7.4 to give concentration of $100 \mathrm{ppm} .1 \mathrm{ml}$ of the above solution was diluted up to $10 \mathrm{ml}$ in a volumetric flask to give concentration of $10 \mathrm{ppm}$. Wavelength was adjusted from 800$200 \mathrm{~nm}$ to find the absorbance maxima.

\section{Preparation of proniosomal suspension}

Proniosomes were formulated using the coacervation phase separation method, with some advancements using different surfactants from Span and Tween for topical application. The composition of different proniosomal formulations is outlined in table 1 . In a glass vial, $10 \mathrm{mg}$ of Amphotericin B was added along with the surfactant and cholesterol. Add the required quantity of ethanol and heat it over a water bath at about $60-70{ }^{\circ} \mathrm{C}$ for 5 min by closing the glass tube to prevent loss of solvent while shaking until the complete dissolution of cholesterol. After complete dissolution of the solution, add $1 \mathrm{ml}$ of phosphate buffer saline and warm for another 5 min until the formation of a clear or translucent solution. The formulation was cooled down at room temperature to get a clear milky white solution of proniosomes [11].

\section{Preparation of proniosomal gel}

In distilled water, a solution of carbopol 934 (2\% w/v) was allowed to swell for 3-4 h. $2 \mathrm{ml}$ of proniosomal suspension was added into carbopol 934 containing glycerin, methyl paraben and mixed with mechanical stirring. Triethanolamine was added to adjust $\mathrm{pH}$ and was sonicated for $15 \mathrm{~min}$ and kept overnight to remove air bubbles [12].

Table 1: Composition of proniosomal suspension

\begin{tabular}{|c|c|c|c|c|c|c|c|c|c|}
\hline \multirow[t]{2}{*}{ Formulation ingredients } & \multicolumn{9}{|c|}{ Formulation code } \\
\hline & F1 & F2 & F3 & F4 & F5 & F6 & F7 & F8 & F9 \\
\hline Amp B (mg) & 10 & 10 & 10 & 10 & 10 & 10 & 5 & 5 & 5 \\
\hline Cholesterol (mg) & 25 & 25 & 25 & 25 & 25 & 25 & 15 & 15 & 15 \\
\hline Soya Lecithin (mg) & 50 & 50 & 50 & 50 & 50 & 50 & 30 & 30 & 30 \\
\hline Span $40(\mathrm{mg})$ & 250 & - & - & - & - & - & 150 & - & - \\
\hline Span 60 (mg) & - & 250 & - & - & - & - & - & 150 & - \\
\hline Span 80 (mg) & - & - & 250 & - & - & - & - & - & 150 \\
\hline Tween 20 (mg) & - & - & - & 250 & - & - & - & - & - \\
\hline Tween 60 (mg) & - & - & - & - & 250 & - & - & - & - \\
\hline Tween 80 (mg) & - & - & - & - & - & 250 & - & - & - \\
\hline Ethanol (ml) & 0.5 & 0.5 & 0.5 & 0.5 & 0.5 & 0.5 & 0.5 & 0.5 & 0.5 \\
\hline Phosphate buffer saline (ml) & Upto $2 \mathrm{ml}$ & Upto $2 \mathrm{ml}$ & Upto $2 \mathrm{ml}$ & Upto $2 \mathrm{ml}$ & Upto $2 \mathrm{ml}$ & Upto $2 \mathrm{ml}$ & Upto $2 \mathrm{ml}$ & Upto $2 \mathrm{ml}$ & Upto $2 \mathrm{ml}$ \\
\hline
\end{tabular}

\section{Vesicle size and shape}

\section{By optical microscope}

Proniosomal suspension $(0.1 \mathrm{~g})$ was diluted with phosphate buffer $\mathrm{pH} 7.4(10 \mathrm{ml})$ and sonicated for about $2 \mathrm{~min}$. A drop was placed on a glass slide and the shape of vesicles was measured using an optical microscope at magnification powers of $10 \mathrm{X}, 45 \mathrm{X}$ and pictograms were recorded [13].

\section{Measurement of vesicle size}

The mean particle size diameter and size distribution (poly dispersity index, PI) were determined by the Malvern Zeta sizer. Each sample was run 3 times and analysis was continued at $25^{\circ} \mathrm{C}$ with a scattering angle of $173^{\circ} \mathrm{C}[14]$.

\section{By scanning electron microscope}

The surface morphology of proniosomes was studied by Scanning Electron Microscopy (SEM). The shape of the formulation and the sizes of the vesicles were determined by SEM. A drop of proniosomal suspension was placed on the specimen stub which was coated with carbon and then with gold vapour appeared using a Hitachi vacuum evaporator. The samples were examined under a scanning electron microscope for vesicular shape and then photographed [15].

\section{Determination of zeta potential}

The zeta potential of the proniosomal formulation was analyzed at $25{ }^{\circ} \mathrm{C}$ using Zeta sizer. Proniosomal suspension was diluted 100 times with doubled-distilled water and voltage was set at $1.4 \mathrm{~V}$ and electrodes were placed in dispersion for the measurement of zeta potential. Each sample was run 3 times and analysis was continued at $25^{\circ} \mathrm{C}$ with a scattering angle of $173^{\circ} \mathrm{C}[16]$.

\section{Determination of entrapment efficiency by centrifugation}

The proniosomal suspension $(0.1 \mathrm{~g})$ was taken in a test tube and reconstituted with $10 \mathrm{ml}$ Isotonic phosphate buffer of $\mathrm{pH}$ 7.4. This aqueous solution was sonicated in a sonicator bath. The drug containing niosomes were separated from the dispersion by centrifugation at $3000 \mathrm{rpm}$ for $30 \mathrm{~min}$ at $20^{\circ} \mathrm{C}$. The supernatant $(1$ $\mathrm{ml}$ ) was taken and diluted with phosphate buffer (in $10 \mathrm{ml}$ volumetric flask). And again, from stock solution, $1 \mathrm{ml}$ was withdrawn and transferred to a $10 \mathrm{ml}$ volumetric flask and made up to the mark with buffer. The drug concentration in the resulting solution was assayed by UV-visible spectroscopy method. The percentage of drug encapsulation was calculated by the following formula: [17]

$$
\mathrm{EE}(\%)=[(\mathrm{Ct}-\mathrm{Cr}) / \mathrm{Ct}] \times 100
$$

Where, EE= Entrapment Efficiency,

$\mathrm{C}_{\mathrm{t}}=$ Concentration of total drug,

$\mathrm{C}_{\mathrm{r}}=$ Concentration of unentrapped drug

\section{Drug content}

\section{Standard Preparation}

Standard solution was prepared with $10 \mathrm{mg}$ of Amphotericin B dissolved in $1 \mathrm{ml}$ of ethanol and $4 \mathrm{ml}$ of phosphate buffer $\mathrm{pH} 7.4$ in a $10 \mathrm{ml}$ volumetric flask. Diluted and made up to $10 \mathrm{ml}$ phosphate buffer $\mathrm{pH} 7.4$

\section{Sample preparation}

Weigh $2 \mathrm{ml}$ of suspension containing $10 \mathrm{mg}$ of drug and add $1 \mathrm{ml}$ of ethanol and $4 \mathrm{ml}$ of phosphate buffer to a $10 \mathrm{ml}$ volumetric flask and 
sonicate until dissolved. Make up the final volume with buffer. Absorbance was measured at $408 \mathrm{~nm}$ [18].

$$
\begin{gathered}
\text { Drug Content (DC): } \frac{\text { Sample Absorbance }}{\text { Standard Absorbance }} \text { X Dose } \\
\text { \%Drug Content: - DC X 100/Dose }
\end{gathered}
$$

\section{Evaluation of proniosomal gel}

\section{Physical appearance and homogeneity}

The physical appearance and homogeneity of the prepared gels were tested by visual observations after the gel had been set in the container. They were analysed for their appearance and the existence of any aggregates [19].

\section{Viscosity}

The measurement of the viscosity of the prepared proniosomal gel was done with a Brookfield Viscometer (DV-E). $10 \mathrm{~g}$ of gel formulation was measured by rotating the spindle 64 at $12 \mathrm{rpm}$ at $37{ }^{\circ} \mathrm{C}$ because gel comes under the High Viscosity (HA) category [20].

\section{Measurement of $\mathrm{pH}$}

The $\mathrm{pH}$ measurements are performed in triplicate using a digital $\mathrm{pH}$ meter. Before measurements, the $\mathrm{pH}$ meter was calibrated and readings were taken by dipping the glass electrode into the gel formulations [21].

\section{Spreadability}

The Spreadability was identified with the following procedure: $0.5 \mathrm{~g}$ of gel was placed within a circle of $1 \mathrm{~cm}$ diameter premarked on a glass plate over which a second glass plate was placed. A weight of $50 \mathrm{~g}$ was allowed to rest on the upper glass plate. Due to spreading of the gels, the diameter was increased and noted. The time in s taken in order to separate the two slides was measured as Spreadability. The mean diameter was determined by repeating the experiment thrice [22].

$$
\mathrm{S}=\mathrm{mXL/t}
$$

Where,

S: Spreadability;

m: weight of load;

L: length travelled by upper slide;

$\mathrm{t}$ : time in seconds

\section{Drug content}

\section{Standard preparation}

Standard solution was prepared with $10 \mathrm{mg}$ of Amphotericin B dissolved in $1 \mathrm{ml}$ of ethanol and $4 \mathrm{ml}$ of phosphate buffer $\mathrm{pH} 7.4$ in a $10 \mathrm{ml}$ volumetric flask. Diluted and made up to $10 \mathrm{ml}$ of $\mathrm{pH} 7.4$ phosphate buffer.

\section{Sample preparation}

Weigh $2 \mathrm{~g}$ of gel containing $10 \mathrm{mg}$ of drug and add $1 \mathrm{ml}$ of ethanol and $4 \mathrm{ml}$ of phosphate buffer to a $10 \mathrm{ml}$ volumetric flask and sonicate until dissolved. Make up the final volume with the buffer. The resulting solution was filtered using Whatman filter paper, and $1 \mathrm{ml}$ of filtered solution was taken and transferred into a volumetric flask containing $10 \mathrm{ml}$ of phosphate buffer $\mathrm{pH} 7.4$ and the volume was made up to the mark with phosphate buffer $\mathrm{pH} 7.4$ and absorbance was measured at $408 \mathrm{~nm}$ [23].

\section{Extrudability}

The extrusion of the gel from the tube is an important aspect during its application and patient acceptance. This study is helpful in elaborating whether the gel has the ability to remove itself from the collapsible tube during application. Viscous gels may not extrude easily from the tube, whereas less viscous gels may flow readily, and hence, suitable consistency is required in order to extrude the gel from the tube. The formulations were filled into the collapsible aluminium tubes. The tubes were stressed to extrude $0.5 \mathrm{~cm}$ of gel in $10 \mathrm{~s}$, and the extrudability of formulations were analyzed [24].

\section{In vitro drug release study}

An in vitro drug release study of proniosomal gel was carried out by using a dialysis bag with a $70 \mu$ pore size as the donor compartment. Proniosomal gel equivalent to $10 \mathrm{mg}$ was taken in a dialysis bag, placed in a buffer containing phosphate buffer solution $\mathrm{pH} 7.4$ which acted as receptor compartment. Before use, a standard dialysis membrane was soaked in $\mathrm{pH} 7.4$ for $24 \mathrm{~h}$ or it can be soaked in warm water for $10 \mathrm{~min}$. Both ends were sealed with thread by adding a proniosomal gel formulation. The dialysis membrane with gel was tied to the paddle apparatus with a dissolution medium (phosphate buffer pH 7.4) of $500 \mathrm{ml}$ at a speed of $50 \mathrm{rpm}$ and maintained at $37^{\circ} \mathrm{C}$. At a predetermined interval of $24 \mathrm{~h}$, samples were withdrawn and replaced with $3 \mathrm{ml}$ of fresh phosphate buffer solution to maintain the sink condition throughout the experiment. The samples withdrawn were diluted and analysed by a UV-visible spectrophotometer at $408 \mathrm{~nm}$ [25].

\section{In vitro diffusion studies}

An in vitro diffusion study was performed by using Franz diffusion cell assembly. It consists of two compartments, one of the receptor chambers containing a Phosphate Buffer Saline (PBS) of pH 7.4 and another donor compartment containing proniosomal gel of $10 \mathrm{mg}$ of the drug. A dialysis membrane (molecular size 12000-14000) was previously soaked for $24 \mathrm{~h}$. The dialysis membrane was placed in contact with PBS filled in the receptor compartment to avoid disruption in the ongoing process; it was ensured that no air bubbles were seen between the dialysis membrane and the liquid surface of PBS. The temperature was maintained at $37^{\circ} \mathrm{C} \pm 0.5$ at $50 \mathrm{rpm}$ using a magnetic stirrer. $0.5 \mathrm{ml}$ of the sample was withdrawn from the receptor chamber side tube at the time interval of $15 \mathrm{~min}, 30 \mathrm{~min}, 45$ min, $1 \mathrm{~h}, 2 \mathrm{~h}, 4 \mathrm{~h}, 6 \mathrm{~h}, 8 \mathrm{~h}, 12 \mathrm{~h}$, and $24 \mathrm{~h}$ and equilibrated with a new or fresh dissolution medium to maintain a sink state. Suitable dilution was carried out and was spectroscopically analysed at a $\lambda$ max of $240 \mathrm{~nm}$ using UV-visible spectroscopy (Shimadzu, UV-1800) [15].

\section{Ex-vivo permeability study}

A skin permeation study was performed using a Franz diffusion cell with an effective diffusion area. The experiment was carried out using freshly killed goat dorsal skin obtained from the local slaughter house and stored at $18^{\circ} \mathrm{C}$ in the physiological salt solution. The skin was first flushed with a physiological solution at room temperature for $2 \mathrm{~h}$ to remove any skin content. Skin was shaved using a blade to remove subcutaneous tissue and the dermis side was cleaned with isopropyl alcohol to remove adhering fat. The cleared skin was cleaned with distilled water. A circular piece of skin (about $3 \mathrm{~cm}$ ) was sandwiched between the donor and receptor compartment of the vertical diffusion chamber and $1 \mathrm{~g}$ of drug loaded proniosomal gel was added to the mucosal side. In the donor compartment, the formulation was placed in intimate contact with the skin. The receptor compartment was filled with phosphate buffer $\mathrm{pH} 7.4$, kept at $37^{\circ} \mathrm{C} \pm 5$, and stirred with a magnetic stirrer. At appropriate intervals, $3 \mathrm{ml}$ aliquots of the receptor medium was withdrawn and immediately replaced with an equal volume of fresh receptor solution. Samples were analysed by UV-visible spectrophotometer at $408 \mathrm{~nm}$ using phosphate buffer $\mathrm{pH} 7.4$ as blank [26].

\section{Anti-fungal studies}

Candida albicans slant as obtained from the microbiology department of Patkar College, Mumbai. $5 \mathrm{ml}$ Sabouraud Dextrose Broth (SDB) was added to the slant and incubated for $24 \mathrm{~h}$ for the growth of Candida albicans. 2.6g of Sabouraud Dextrose Agar (SDA) was added to $40 \mathrm{ml}$ of distilled water in conical flask and stoppered with a cotton plug and autoclaved for $15 \mathrm{~min}$ at $15 \mathrm{lbs}$ of pressure. After cooling it at room temperature, pour $20 \mathrm{ml}$ into two sterile petri plates between two flames, swirl the plates to remove air bubbles, and let it solidify at room temperature near the sterile area. Addition of Candida albicans through a cotton swab and streaked in all directions into the solidified agar, bore four wells from the sterile borer to add the proniosomal gel formulation. Incubate at $25-30{ }^{\circ} \mathrm{C}$ 
for $72 \mathrm{~h}$ for inhibition of fungi and observe the Zone of Inhibition and measure the diameter in $\mathrm{mm}$; the greater the zone of inhibition, the more susceptible is the formulation [27].

\section{Stability study}

Th stability of the proniosomal suspension was performed as per International Council on Harmonisation (ICH) guidelines for $3 \mathrm{mo}$. sufficient quantities of the proniosomal gel formulations were sealed in $10 \mathrm{~g}$ collapsible aluminium tubes in triplicate. The samples were withdrawn at each mo over a period of $3 \mathrm{mo}$, and leakage of drug from the formulation was analysed for drug content by using a UVvisible spectrophotometer [28].

\section{RESULTS AND DISCUSSION}

\section{Determination of melting point of the drug}

The Melting point of Amphotericin B was found to be in the range of $97.8{ }^{\circ} \mathrm{C}-199{ }^{\circ} \mathrm{C}$ shown in fig. 7 and it complies with the Indian Pharmacopoeia (IP) standard, thus indicating the purity of the sample.

\section{Drug excipient compatibility studies by FTIR}

The Fourier Transform Infrared Radiation (FT-IR) spectrum of Amphotericin B powder was shown in fig. 1. The results reveal identical spectra for the tested powder and the reference. Where, characteristic peaks and other principle peaks are shown in table No. 2. The structural characterization of cholesterol was performed by recording FT-IR spectra of the samples. The comparison between the spectrum of pure Amphotericin B powder with cholesterol shows the presence of Amphotericin B and cholesterol bands similar to each one alone. No incompatibilities was present and no new bands appear as shown in fig. 2. The spectra in the mixture of Amphotericin B with span 60 are similar to those in fig. 4. No drug interaction was present and no new bands appeared. The Infrared Radiation (IR) spectrum of Amphotericin B (drug), physical mixture with excipients in fig. 6, was recorded and it was found in accordance with the reported peaks. There were no observed significant peak shifts and no generation of a new peak, although there might be no possible interaction between drug and excipients. The FTIR spectrum was found to be unadulterated, stable and unaltered [29].

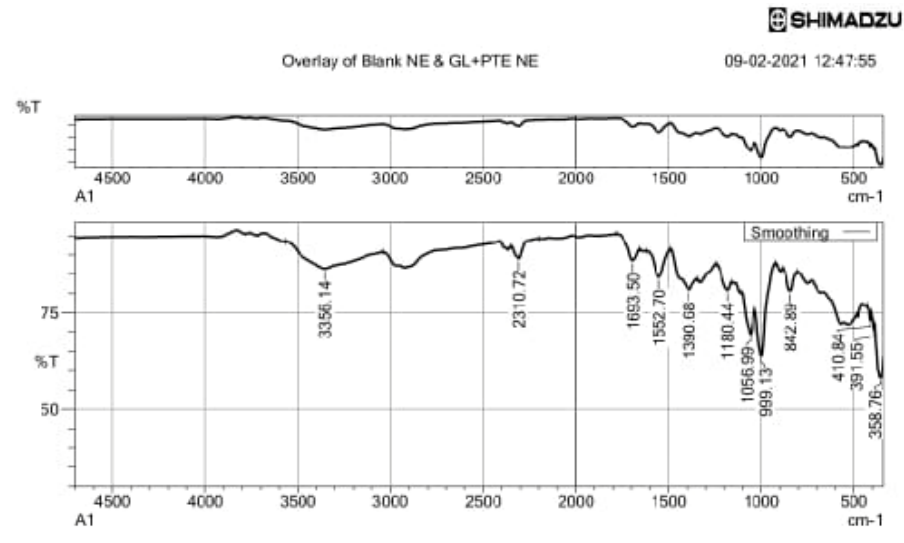

Fig. 1: IR spectrum of pure amphotericin $B$

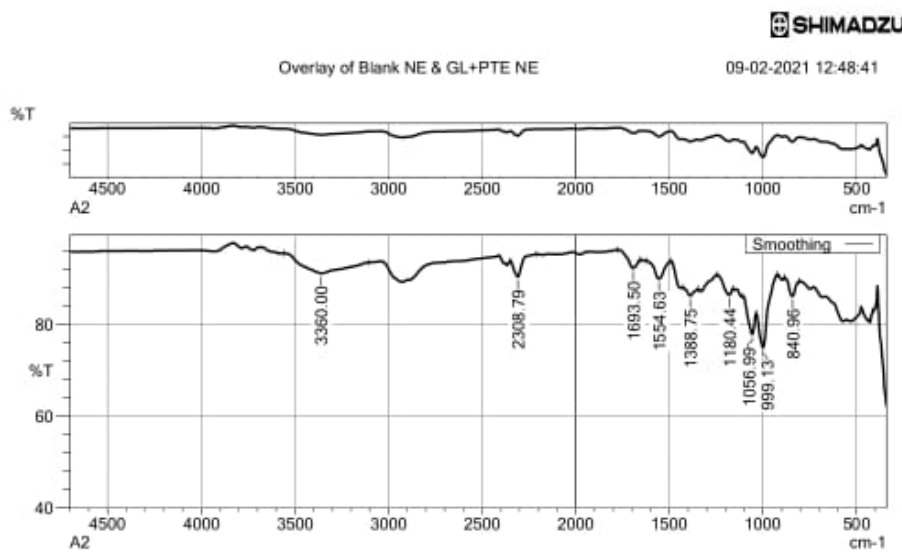

Fig. 2: IR spectrum of amphotericin B and cholesterol

Table 2: Infrared spectral assignment for amphotericin B

\begin{tabular}{llllllll}
\hline $\begin{array}{l}\text { S. } \\
\text { No. }\end{array}$ & $\begin{array}{l}\text { Functional } \\
\text { group }\end{array}$ & $\begin{array}{l}\text { Reported } \\
\text { frequency } \\
\text { (cm-1) }\end{array}$ & $\begin{array}{l}\text { Frequency } \\
\text { of drug } \\
\text { (cm-1) }\end{array}$ & $\begin{array}{l}\text { Frequency of drug } \\
\text { and cholesterol } \\
\text { (cm-1) }\end{array}$ & $\begin{array}{l}\text { Frequency of drug } \\
\text { and soya lecithin } \\
\text { (cm-1) }\end{array}$ & $\begin{array}{l}\text { Frequency of } \\
\text { drug and Span 60 } \\
\text { (cm-1) }\end{array}$ & $\begin{array}{l}\text { Frequency of drug } \\
\text { and carbopol (cm- } \\
\text { 1) }\end{array}$ \\
\hline 1. & O-H (S) & $3500-3200$ & 3356.14 & 3360.00 & 3352.28 & 3358.07 & - \\
2. & C=O(S) & $1760-1690$ & 1693.50 & 1693.50 & 1732.08 & 1693.50 & 1693.50 \\
3. & $=\mathrm{C}-\mathrm{H}$ bend & $1000-650$ & 999.13 & 999.13 & 999.13 & 999.13 \\
4. & C-O (S) & $1300-1000$ & 1180.44 & 1180.44 & 1178.51 & 1180.44 & 1174.65 \\
5. & N-H Aromatic & $3250-3400$ & 3356.14 & 3360.00 & 3352.28 & 3358.07 & - \\
\hline
\end{tabular}

From the above results, it could be inferred that the drug remained intact and no chemical interaction appeared to occur between the drug and excipients therein. 


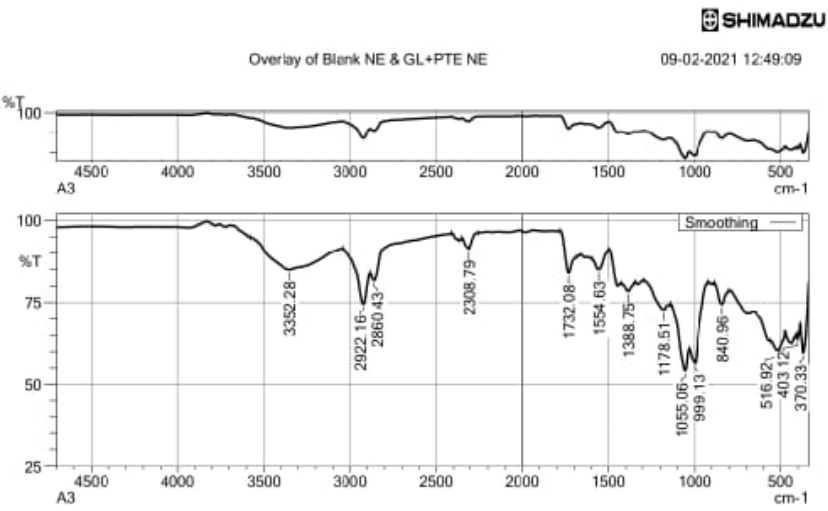

Fig. 3: IR spectrum of amphotericin B and soya lecithin

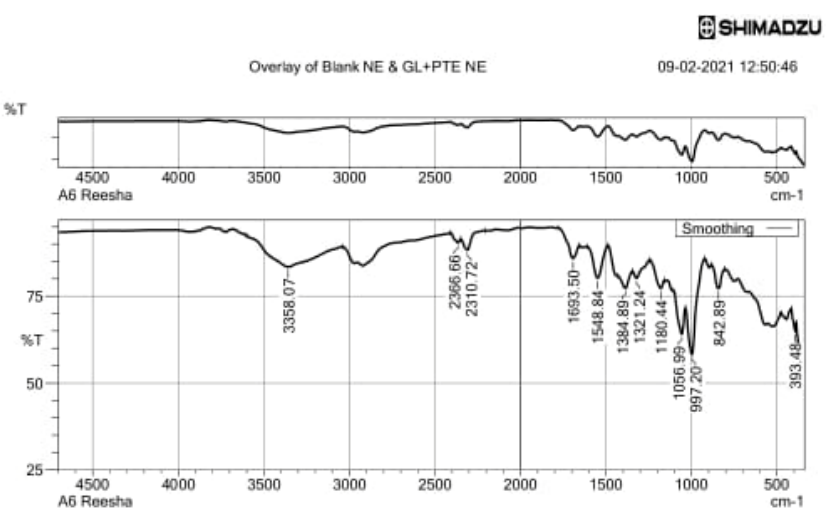

Fig. 4: IR spectrum of amphotericin B and span 60

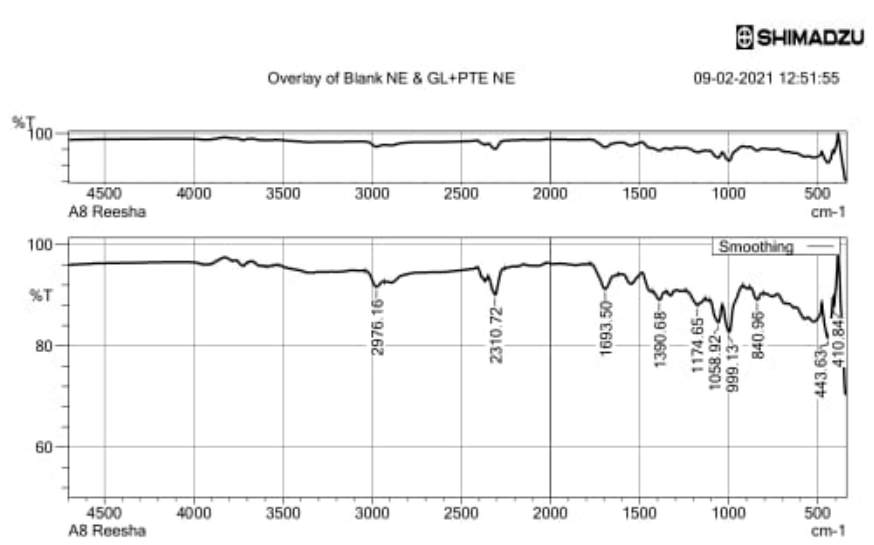

Fig. 5: IR spectrum of amphotericin B and carbopol 934

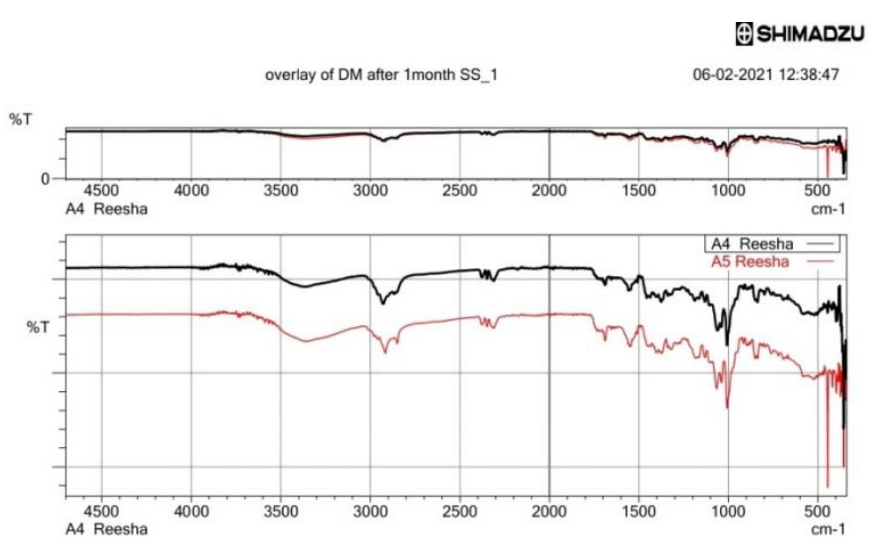

Fig. 6: IR spectrum of amphotericin b and physical mixture (Span 60, Cholesterol, Soya Lecithin, Carbopol 934) 


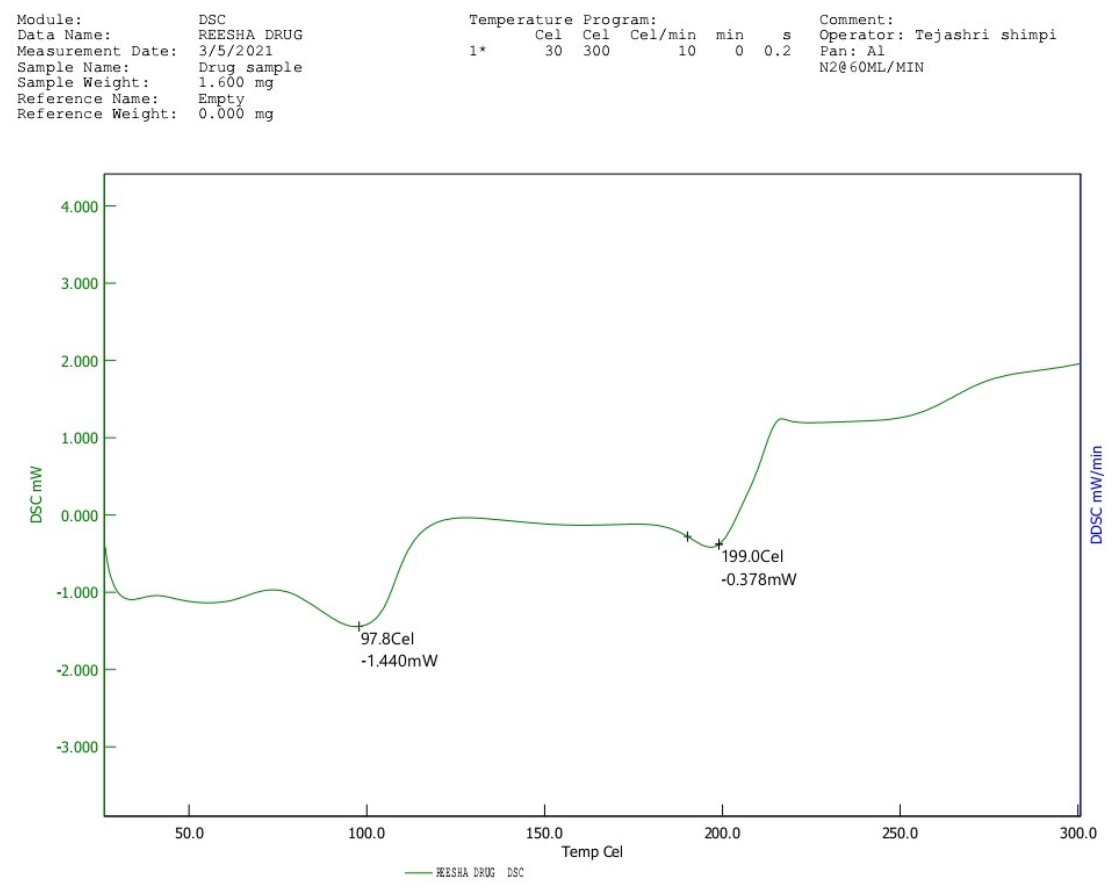

Fig. 7: Differential scanning calorimeter (DSC) thermogram of amphotericin B

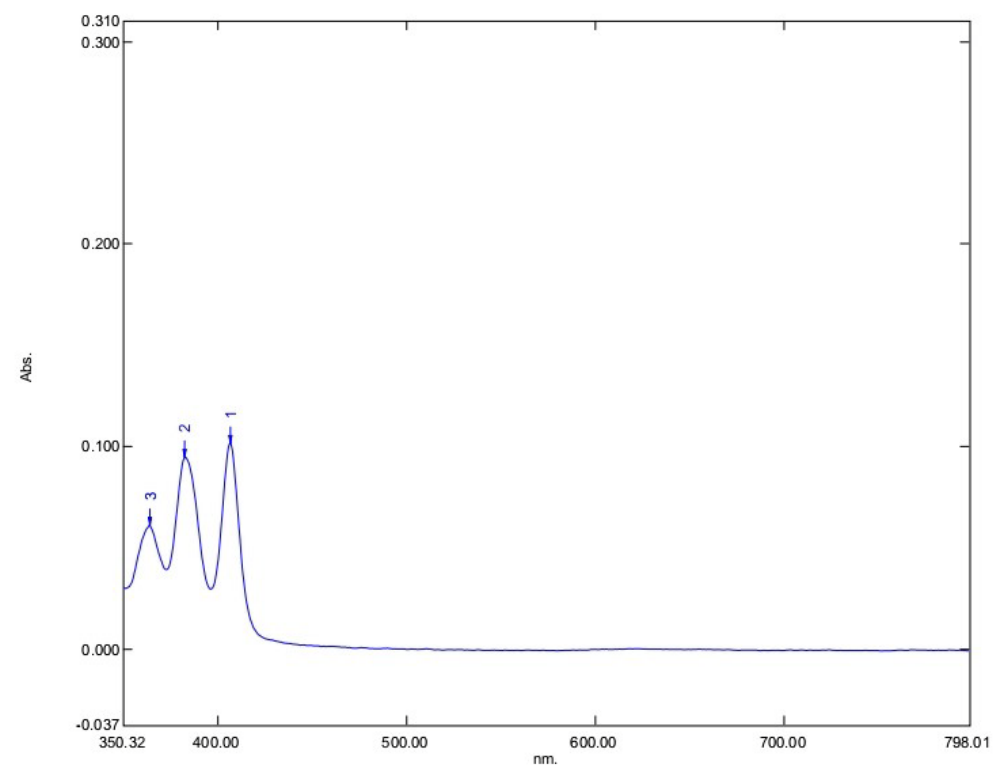

Fig. 8: UV spectrum of amphotericin B at $408 \mathrm{~nm}$

\section{DSC thermogram of drug}

The DSC thermogram of drug showed a broad endothermic peak due to the loss of moisture attributed to the loss of adsorbed water (Amp $\mathrm{B}$ is hygroscopic in nature). Two characteristic endothermic peaks were observed for Amp B at $97.8^{\circ} \mathrm{C}$ to $199.0{ }^{\circ} \mathrm{C}$ as shown in fig. 7 . Similar findings were observed in the reference. However, the complete disappearance of the characteristic endothermic peaks for Amp B from the thermograms was a strong evidence of an amorphous transformation that is favourable to rapid bioavailability during in vivo drug release [30].

\section{Determination of $\lambda$ max}

A concentration of $10 \mu \mathrm{g} / \mathrm{ml}$ was prepared from a standard Amphotericin B solution scanned by a UV-visible spectrometer in the range of $200-800 \mathrm{~nm}$ using $\mathrm{pH} 7.4 \mathrm{PBS}$ as a blank, then the maximum wavelength $(\lambda \max )$ was determined as shown in fig. 6 .

\section{Evaluation of prepared proniosomal suspension}

\section{Vesicle size and shape}

\section{By optical microscope}

Optical microscope under $45 \mathrm{x}$ showed the size range of vesicles are decreased in the sequence of $\mathrm{F} 1>\mathrm{F} 2>\mathrm{F} 3$ that correspond to span 40 , span 60 and span 80, respectively. The results obtained as shown in the fig. 9 indicated that the mean size of the proniosomes showed a regular increase with increasing the hydrophilic lipophilic balance (HLB) of the surfactant because surface free energy decreases with increasing hydrophobicity [31]. Generally, the surfactant with longer 
alkyl chains shows smaller vesicles because the diameter of vesicles is dependent on the length of the alkyl chains of surfactants [32].

\section{Measurement of vesicle size}

The particle size distribution profile of proniosomal suspension (Particle size d. nm vs intensity \%) was found to be $211.5 \mathrm{~nm}$ as shown in fig. 10. The uniformity of vesicle size is determined by polydispersity index (PI) values, in which the lower the value, the more uniformity in size. The lower the PI value, the more monodispersed and homogeneous the dispersion. The polydispersity index (PI) value was $\mathrm{PI}=0.956$, which is a measure of the uniformity of proniosome size within the formulation [33].

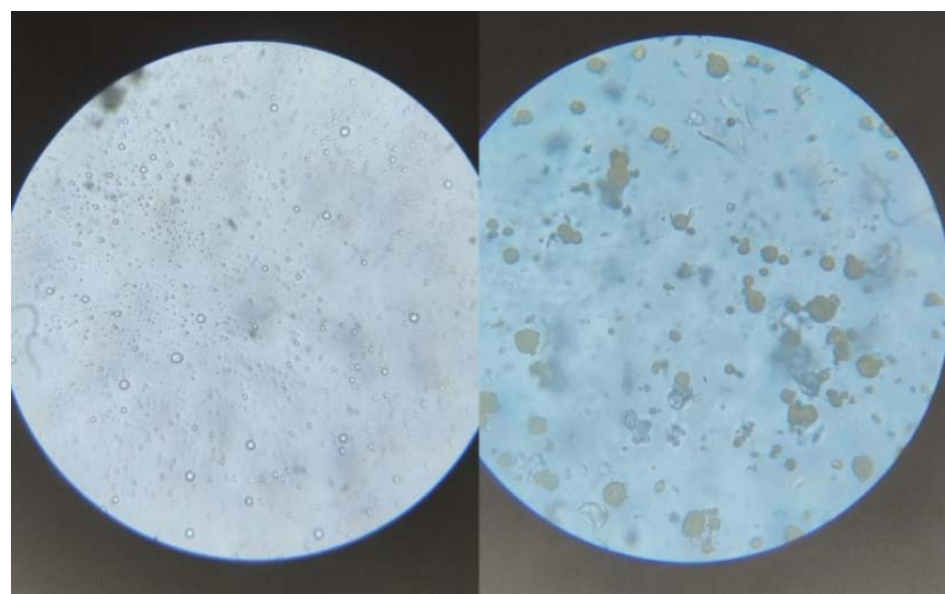

A

B

Fig. 9: F2 Proniosomal vesicles under optical microscope 45x, (A) without drug and (B) entrapped drug (2 ml)

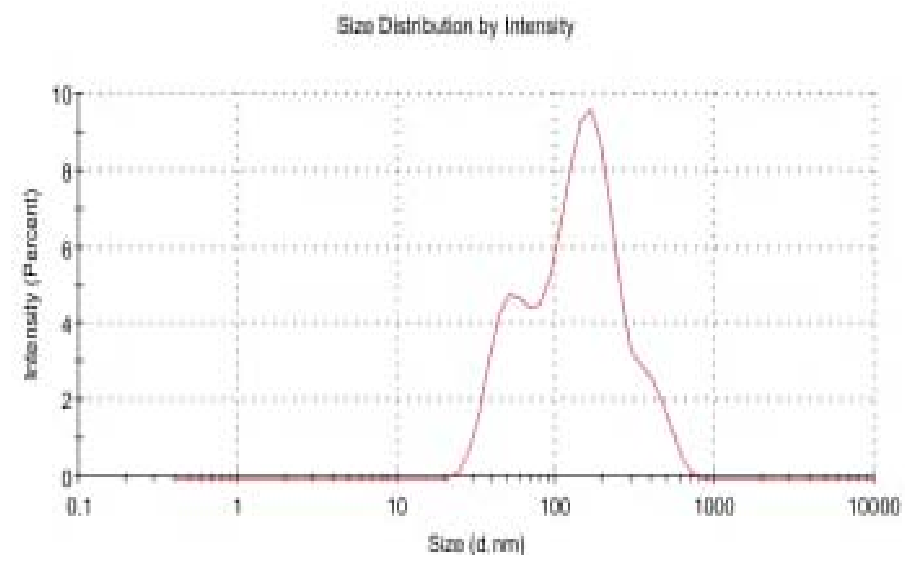

Fig. 10: Particle size distribution of F2 proniosomal suspension ( $2 \mathrm{ml})$

\section{By scanning electron microscope (SEM)}

Surface morphological properties of formula F2 nano size vesicles were obtained by SEM at three magnifications $(1.00 \mathrm{~K} \mathrm{X}, 5.00 \mathrm{~K} \mathrm{X}$,
$10.00 \mathrm{~K} \mathrm{X}$ ) and shown in fig. 11. The vesicular properties of these drug carriers form double layers. SEM revealed the morphology of the vesicles and the arrangement of the lamellar structure encapsulating the drug molecules [34].

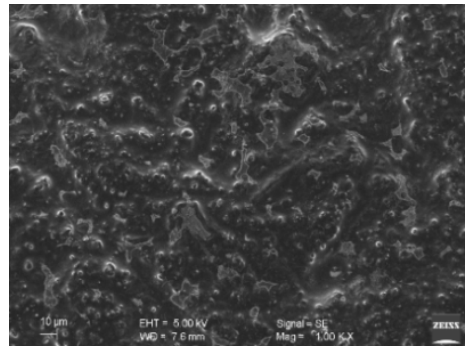

(A)

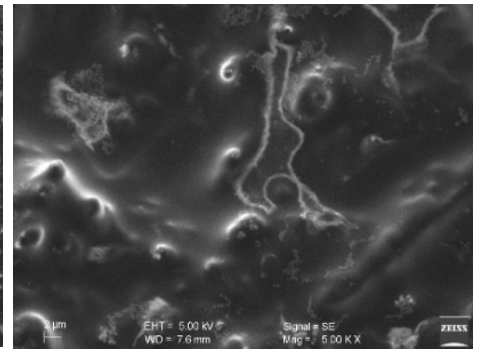

(B)

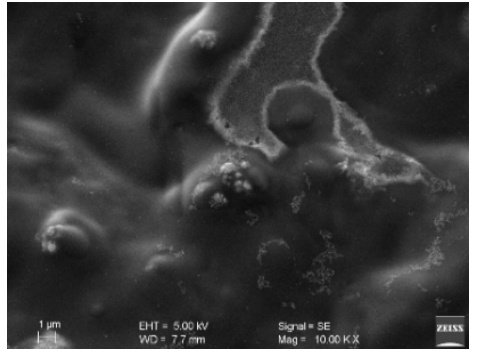

(C)

Fig. 11: Scanning electron micrographs of proniosomal formula $F 2$ at three different magnification powers (A)1.00 K X, (B)5.00 K X, (C)10.00 K X) 


\section{Determination of zeta potential}

The formulation F2 which was subjected to zeta potential analysis had a zeta value of $-1.57 \mathrm{mV}$ as shown in the fig. 12, which is a measure of net charge of proniosomes. The high surface charge provides sufficient electrostatic repulsion between the vesicles, which makes them stable by preventing aggregation [35].

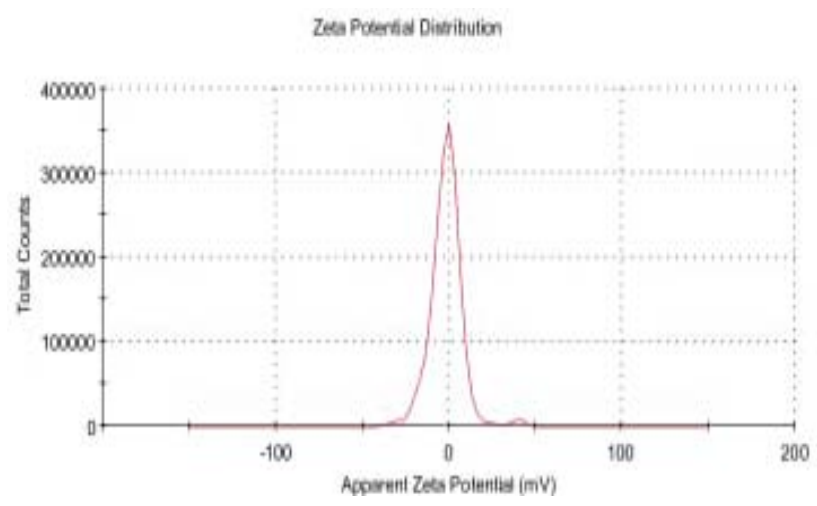

Fig. 12: Zeta potential analysis of proniosomal suspension $(2 \mathrm{ml})$

\section{Determination of entrapment efficiency by centrifugation}

Higher entrapment efficiency of the vesicles of a formulation containing surfactant Span 60 is expected due to its higher alkyl chain length. The F2 formulation showed the highest entrapment efficiency of $94.20 \% \pm 0.20$, which may have an optimum surfactant cholesterol ratio to provide a high entrapment of Amp B. The proniosomal formulations having high surfactant concentration (F1, F2, and F3) showed higher entrapment efficiency, which might be due to the high fluidity of the vesicles. The formulation with very low cholesterol content (F7) was also found to cause low entrapment efficiency $(75.16 .15 \pm 0.15 \%)$ which might be because of leakage of the vesicles. It was also observed that a formulation with very high cholesterol content (F2) had a low effect on drug entrapment. This could be because cholesterol beyond a certain level starts disrupting the regular bi-layered structure, leading to the loss of drug entrapment. Entrapment efficiency obtained for all the formulations is given in table 3 [36].

\section{Drug content}

The percent of drug content for all the formulations F1 to F9 was obtained in the range of $89.71 \% \pm 0.53$ to $95.16 \% \pm 0.40$. The results given in table 3 indicate that the drug is distributed uniformly in all film formulations and will deliver the dose of drug accurately.

Table 3: Evaluation of proniosomal suspension of amphotericin B (2 ml)

\begin{tabular}{lll}
\hline Formulation code & Drug content (\%) & Entrapment efficiency (\%) \\
\hline F1 & $89.71 \% \pm 0.53$ & $84.26 \pm 0.25$ \\
F2 & $95.16 \% \pm 0.40$ & $94.20 \pm 0.20$ \\
F3 & $93.41 \% \pm 0.23$ & $81.46 \pm 0.45$ \\
F4 & $94.08 \% \pm 0.23$ & $80.4 \pm 0.36$ \\
F5 & $93.14 \% \pm 0.20$ & $78.33 \pm 0.30$ \\
F6 & $92.87 \% \pm 0.30$ & $79.2 .16 \pm 0.15$ \\
F7 & $93.75 \% \pm 0.20$ & $75.16 .15 \pm 0.15$ \\
F8 & $93.95 \% \pm 0.20$ & $77.52 .55 \pm 0.04$ \\
F9 & $92.80 \% \pm 0.11$ & $76.33 .23 \pm 0.19$ \\
\hline
\end{tabular}

All data are given in mean $\pm S D, n=3$

\section{Evaluation of prepared proniosomal gel}

\section{Physical appearance and homogeneity}

All the proniosomal gel formulations had pale yellow to vibrant yellow colour, were transparent in appearance, free from presence of particles, and showed good homogeneity with the absence of lumps.

\section{Viscosity}

All the proniosomal gel formulations had sufficient gel-like viscosity.

Viscosity was found to be in the range of $4146 \pm 1$ cps to $4269 \pm 1 \mathrm{cps}$ shown in table 4.

\section{Measurement of $\mathrm{pH}$}

The $\mathrm{pH}$ was noted by $\mathrm{pH}$ meter by dipping into the gel formulation and allowing for equilibration. The $\mathrm{pH}$ of all gels was found to be in the range of $5.8 \pm 0.1$ to $6.4 \pm 0.05 \mathrm{pH}$ given in table 4 , which lies in the normal $\mathrm{pH}$ range of the skin. All the formulation batches show $\mathrm{pH}$ in the neutral range, which indicates for the absence of skin irritation [37].

\section{Spreadability}

The spreadability plays an important role as it shows the behaviour of the gel that comes out of the tube. The result of spreadability shown in table 4 indicate that the polymer used gave a bit of shear to the gel. The diameters of the spread circles ranged from $4.22 \pm 0.02 \mathrm{~cm}$ to $5.19 \pm 0.01 \mathrm{~cm}$ as seen with carbopol gel. Increasing the concentration of the gelling agents causes a decreasenin the spreadability [38].

\section{Drug content}

Table 4 shows the results of drug content. After various formulation of Amp B gel, the drug content of the formulated gel was estimated and the results were within the official limits with a range of $94.24 \% \pm 0.29$ to $97.05 \% \pm 0.19$. The drug content determination also showed that the drug was uniformly distributed throughout the gel and would deliver the dose of drug accurately [39].

\section{Extrudability}

With the increase of material flow rate, all gel formulations lead to a larger extrusion pressure. The increased dosage could lead to a rise in the shear yield stress and flow consistency, which would result in higher extrusion pressure. Table 4 shows the results of extrudability tests [40]. 
Table 4: Evaluation of $2 \% \mathrm{w} / \mathrm{w}$ proniosomal gel of amphotericin B (10g)

\begin{tabular}{lllll}
\hline Formulation code & Viscosity (cps) & pH & Spreadability (cm) & Drug content (\%) \\
\hline F1 & $4115.33 \pm 1.52$ & $6.13 \pm 0.15$ & $4.4 \pm 0.1$ & $95.81 \% \pm 0.29$ \\
F2 & $4269 \pm 1$ & $5.8 \pm 0.1$ & $5.19 \pm 0.01$ & $97.05 \% \pm 0.19$ \\
F3 & $4146 \pm 1$ & $6.43 \pm 0.05$ & $4.22 \pm 0.02$ & $95.88 \% \pm 0.19$ \\
F4 & $4248.33 \pm 0.57$ & $5.86 \pm 0.05$ & $5.18 \pm 0.01$ & $94.50 \% \pm 0.19$ \\
F5 & $4177 \pm 1$ & $6.1 \pm 0.1$ & $4.53 \pm 0.01$ & $95.62 \% \pm 0.45$ \\
F6 & $4215 \pm 1$ & $6.3 \pm 0.1$ & $4.64 \pm 0.01$ & $95.16 \% \pm 0.11$ \\
F7 & $4181 \pm 1$ & $6.4 \pm 0.05$ & $3.86 \pm 0.02$ & $94.31 \% \pm 0.19$ \\
F8 & $4214 \pm 1$ & $6.33 \pm 0.15$ & $4.31 \pm 0.01$ & $94.24 \% \pm 0.29$ \\
F9 & $4174 \pm 1$ & $5.9 \pm 0.1$ & $5.17 \pm 0.01$ & ++ \\
\hline
\end{tabular}

All data are given in mean $\pm \mathrm{SD}, \mathrm{n}=3$

\section{In vitro drug release}

The in vitro release study of Amp B was conducted in phosphate buffer $\mathrm{pH} 7.4$ for release studies through a dialysis bag of Amphotericin B proniosomal gel. This medium throughout maintained sink conditions, and thus release studies were performed. The drug release pattern for $24 \mathrm{~h}$ is depicted in fig. 13 . The release profile indicated a biphasic release of Amp B from the proniosomes. Given in the table no. 5 , in the first phase $(6 \mathrm{~h})$, there was an initial rapid release of about $69.48 \% \pm 0.11-76.58 \% \pm 0.33$ according to the formulation, followed by a slow phase from $6 \mathrm{~h}$ to $24 \mathrm{~h}$ where about $20 \%$ was released. The results showed no lag time which causes a burst in drug release during the first 15 min (about $4-7 \%$ ) of the encapsulated drug in the proniosomes. The highest drug release within $24 \mathrm{~h}$ was obtained with F2 (95.72\% \pm 0.30$)$, while the lowest was F8 (88.006\% 00.04$)$.

Drug release from F1 to F9 was found to be in the range of $88.006 \% \pm 0.04$ to $95.72 \% \pm 0.05$. The formulation F2 was selected as an optimized formulation based on these in vitro release studies, which showed satisfactory drug release rate of $95.72 \% \pm 0.05$ in $24 \mathrm{~h}$. The selected optimized formulation F2 was used further for the evaluation of ex vivo permeation studies through goat skin [41].

Table 5: In vitro drug release of amphotericin B proniosomal gel (10g)

\begin{tabular}{|c|c|c|c|c|c|c|c|c|c|}
\hline \multirow[t]{2}{*}{ Time duration } & \multicolumn{9}{|c|}{ Cumulative \% drug release } \\
\hline & F1 & F2 & F3 & F4 & F5 & F6 & F7 & F8 & F9 \\
\hline $15 \mathrm{~min}$ & $5.60 \pm 0.02$ & $7.70 \pm 0.01$ & $5.39 \pm 0.01$ & $5.39 \pm 0.02$ & $5.20 \pm 0.09$ & $5.28 \pm 0.01$ & $4.15 \pm 0.04$ & $3.85 \pm 0.03$ & $3.89 \pm 0.06$ \\
\hline $30 \mathrm{~min}$ & $12.99 \pm 0.02$ & $16.96 \pm 0.02$ & $12.92 \pm 0.02$ & $12.68 \pm 0.04$ & $12.68 \pm 0.14$ & $12.78 \pm 0.03$ & $11.94 \pm 0.03$ & $11.48 \pm 0.05$ & $11.71 \pm 0.01$ \\
\hline $45 \min$ & $21.54 \pm 0.06$ & $27.44 \pm 0.11$ & $22.80 \pm 0.02$ & $21.32 \pm 0.05$ & $21.36 \pm 0.18$ & $21.52 \pm 0.08$ & $20.37 \pm 0.05$ & $19.50 \pm 0.11$ & $19.90 \pm 0.06$ \\
\hline $1 \mathrm{~h}$ & $31.82 \pm 0.07$ & $39.69 \pm 0.33$ & $34.64 \pm 0.03$ & $31.93 \pm 0.12$ & $31.98 \pm 0.06$ & $31.20 \pm 0.17$ & $30.14 \pm 0.07$ & $28.86 \pm 0.18$ & $29.02 \pm 0.03$ \\
\hline $2 \mathrm{~h}$ & $46.49 \pm 0.04$ & $54.85 \pm 0.33$ & $49.65 \pm 0.04$ & $46.35 \pm 0.12$ & $46.73 \pm 0.17$ & $46.29 \pm 0.16$ & $45.20 \pm 0.06$ & $43.69 \pm 0.14$ & $43.69 \pm 0.04$ \\
\hline $4 \mathrm{~h}$ & $60.82 \pm 0.05$ & $68.19 \pm 0.34$ & $62.86 \pm 0.07$ & $61.20 \pm 0.08$ & $61.80 \pm 0.23$ & $61.27 \pm 0.11$ & $60.90 \pm 0.07$ & $59.10 \pm 0.07$ & $59.10 \pm 0.07$ \\
\hline $6 \mathrm{~h}$ & $70.71 \pm 0.01$ & $76.58 \pm 0.33$ & $71.21 \pm 0.03$ & $71.15 \pm 0.07$ & $71.58 \pm 0.20$ & $71.31 \pm 0.09$ & $70.77 \pm 0.05$ & $69.48 \pm 0.11$ & $69.55 \pm 0.05$ \\
\hline $8 \mathrm{~h}$ & $81.91 \pm 0.01$ & $84.00 \pm 0.33$ & $78.82 \pm 0.06$ & $80.19 \pm 0.07$ & $80.69 \pm 0.14$ & $80.56 \pm 0.07$ & $80.68 \pm 0.07$ & $79.35 \pm 0.13$ & $80.12 \pm 0.09$ \\
\hline $12 \mathrm{~h}$ & $86.62 \pm 0.03$ & $90.96 \pm 0.31$ & $85.66 \pm 0.04$ & $85.85 \pm 0.07$ & $86.32 \pm 0.04$ & $86.31 \pm 0.08$ & $86.40 \pm 0.04$ & $85.84 \pm 0.07$ & $87.24 \pm 0.03$ \\
\hline $24 \mathrm{~h}$ & $91.13 \pm 0.05$ & $95.72 \pm 0.30$ & $90.36 \pm 0.05$ & $90.11 \pm 0.04$ & $91.06 \pm 0.05$ & $91.13 \pm 0.05$ & $88.18 \pm 0.06$ & $88.006 \pm 0.04$ & $88.88 \pm 0.06$ \\
\hline
\end{tabular}

All data are given in mean $\pm \mathrm{SD}, \mathrm{n}=3$

\section{In vitro diffusion studies}

In vitro diffusion of all formulations ranges from $76.27 \% \pm 0.27$ to $82.62 \% \pm 0.16$ depicted in fig. no. 14. In the case of $F$ series formulations, F1, initially, the drug release was rapid, more than $60 \%$ in $2 \mathrm{~h}$ and followed by slow release and showed about $78.79 \% \pm 0.27$ in $24 \mathrm{~h}$ respectively. In $4 \mathrm{~h}$, the formulations F4 and F5 yielded $63.59 \% \pm 0.16$ and $62.75 \% \pm 0.16$, respectively. There was no remarkable difference in the final percentage of drug diffusion due to fact that in all formulations, the drug was dissolved completely in the medium. It is clear from the plots that the drug diffusion was governed by the polymer content. No lag time was observed as the gel was directly exposed to the medium. The formulation F2 was selected as an optimized formulation based on the in vitro diffusion studies which showed a satisfactory diffusion rate $82.62 \% \pm 0.16$ in $24 \mathrm{~h}$. The selected optimized formulation F2 was used further for the evaluation of ex-vivo permeation studies through goat skin [42].

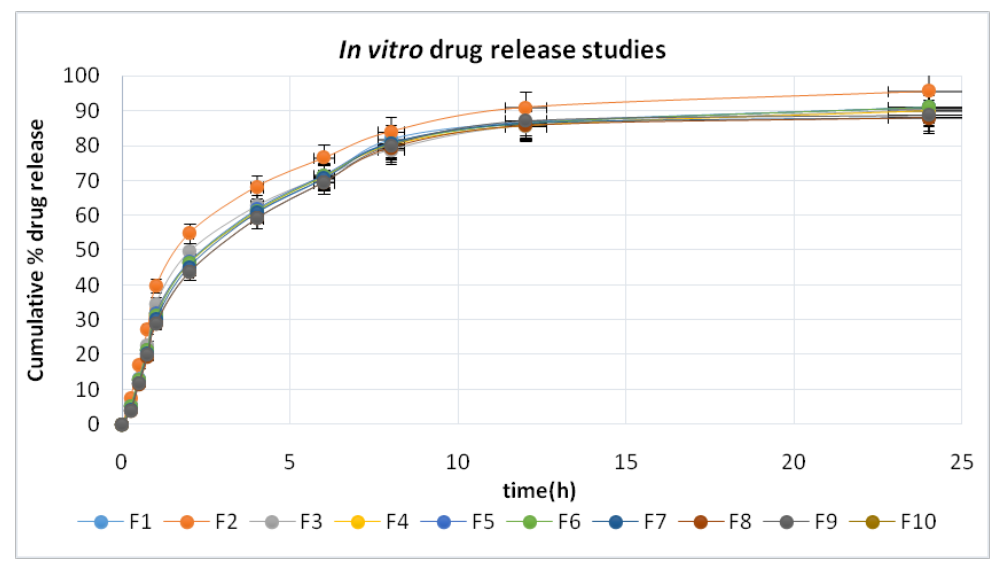

Fig. 13: In vitro drug release profile of $2 \% \mathrm{w} / \mathrm{w}$ of amphotericin B proniosomal gel $(10 \mathrm{~g})$, all data are given in mean \pm Error bars, $n=3$ 


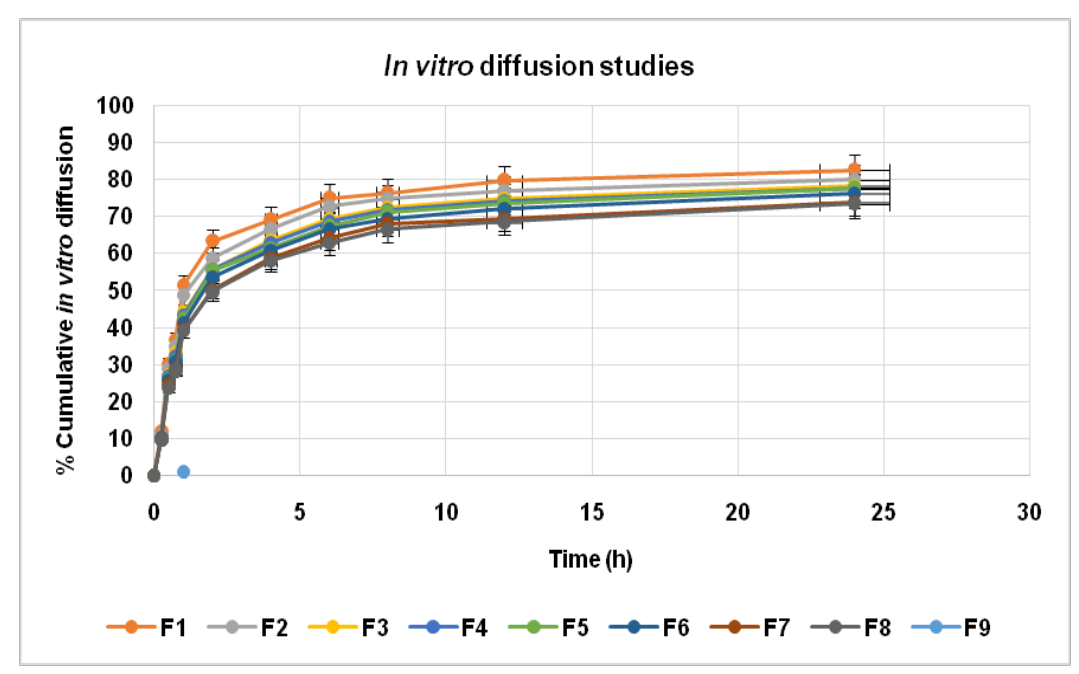

Fig. 14: In vitro diffusion profile of $2 \% \mathrm{w} / \mathrm{w}$ Amphotericin B proniosomal gel, All data are given in mean \pm Error bars, $n=3$

\section{Ex-vivo permeation studies}

The formulation F2 was selected as optimum for the ex-vivo permeation studies due to adequate in vitro drug release, in vitro diffusion studies. The result of drug permeation from the proniosomal gel drug release of Amp B through the goat skin reveals that drug was released from the formulation and permeated through the goat skin and hence can feasibly be permeated through the human skin. The result indicated in the fig. 15 that the drug permeation was slow and steady and $76.55 \% \pm 0.27$ of Amp B permeate through the skin from the optimized formulation in $24 \mathrm{~h}$. The cumulative percentage amount of Amp B that had penetrated through the skin from the proniosomal gel was shown in the fig. 15 [43].

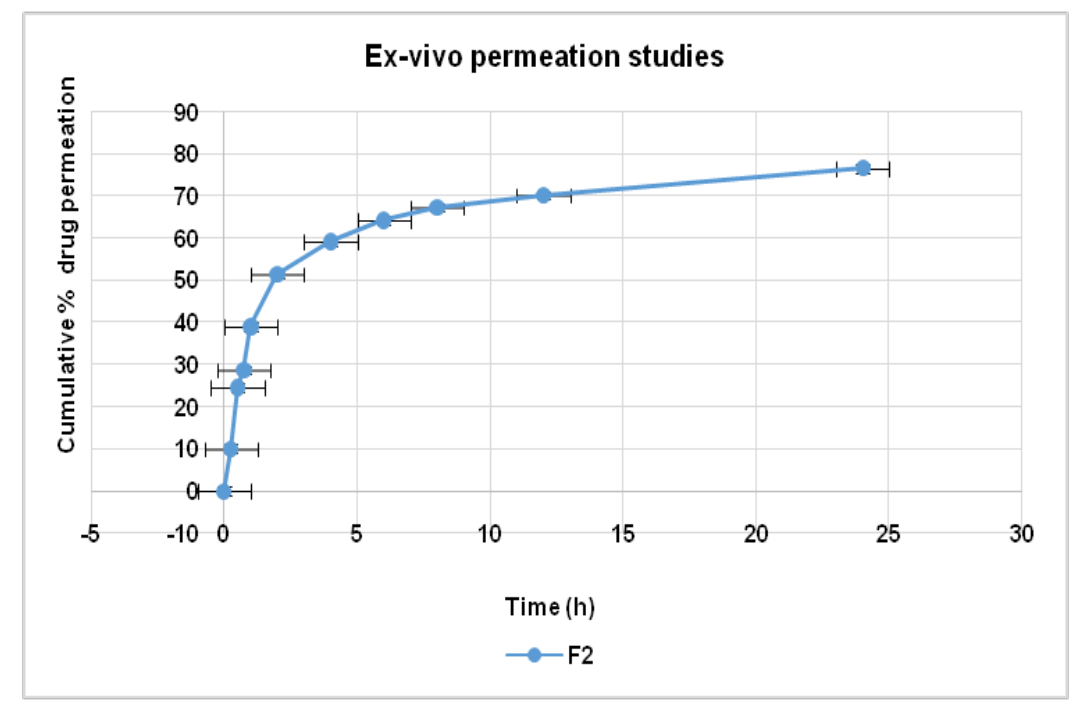

Fig. 15: Ex-vivo permeation of $2 \% \mathrm{w} / \mathrm{w}$ Amphotericin B proniosomal gel, All data are given in mean \pm Error bars, $\mathrm{n}=3$

\section{Anti-fungal studies}

The antifungal activity of Amp B from its different gel formulae compared with control revealed in fig. 16. The antifungal activity was determined by measuring the inhibition zone. The results observed with F2 were greater where the inhibition zone reaches $4.5 \mathrm{~cm}$, while the lowest activity was seen with $\mathrm{F} 8$ where the inhibition was $2.3 \mathrm{~cm}$. This indicates good correlation between the chosen dissolution model and the in vitro antimicrobial susceptibility testing. The obtained results showed that the developed proniosomal gel was more efficient when compared to the control. Fig. 17 shows a comparison between the mean values of inhibition zones of Amp B proniosome gel F2, F5, F8 and control after $48 \mathrm{~h}$. Results indicate that F2 exhibits maximum antifungal activity after $48 \mathrm{~h}[44]$.

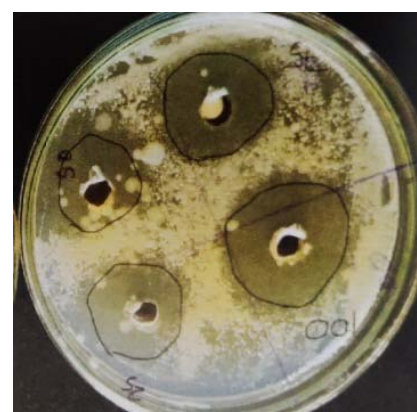

Fig. 16: Antifungal study of 2\% w/w Amphotericin B Proniosomal gel by Agar Plate Method using Candida albicans 


\section{Zone of Inhibition}

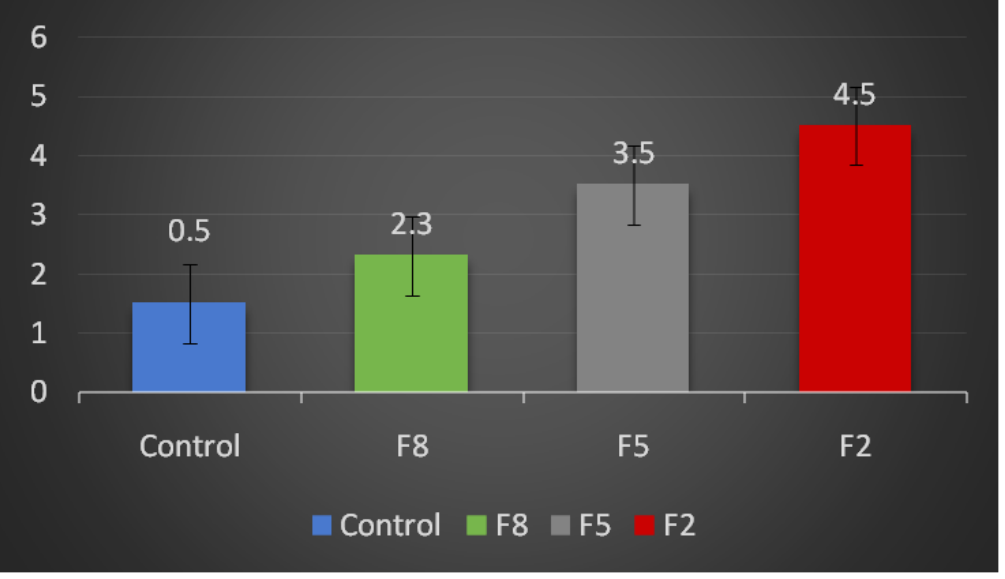

Fig. 17: Zone of inhibition of control gel (a), F8 Amp B gel (b), F5 Amp B gel, (d) F2 Amp B proniosomal gel after 48 h, n=3, all data are given in mean \pm Error bars

\section{Stability studies}

Based on the above results, stability studies were conducted only for optimized formulation F2. From the stability studies, it was known that optimized formulation F2 has stability in human skin; there were no change in the colour and viscosity of the proniosomal gel. A stability study was performed on the optimized formulation $\mathrm{F} 2$ at temperatures $25^{\circ} \mathrm{C} \pm 2$ and $60 \% \pm 5$ Relative Humidity (RH) and at $40^{\circ} \mathrm{C} \pm 2$ and $75 \% \pm 5 \mathrm{RH}$, for short-term and accelerated studies, respectively, for the period of 3 mo. The proniosomal gel was analysed for drug content and in vitro drug release. There was a minor decrease in all the parameters. Hence, the results of formulation F2 showin in table 6 was indicated as stable [45].

Table 6: Short term at $25{ }^{\circ} \mathrm{C}$ and accelerated stability at $40{ }^{\circ} \mathrm{C}$ studies of optimized batch $\mathrm{F} 2$

\begin{tabular}{|c|c|c|c|c|}
\hline \multirow[t]{2}{*}{ Time (d) } & \multicolumn{2}{|c|}{$25^{\circ} \pm 2^{\circ} \mathrm{C} / 60 \% \mathrm{RH} \pm 5 \% \mathrm{RH}$} & \multicolumn{2}{|c|}{$40^{\circ} \pm 2{ }^{\circ} \mathrm{C} / 75 \% \mathrm{RH} \pm 5 \% \mathrm{RH}$} \\
\hline & Drug content $(\%)$ & In vitro drug release $(\%)$ & Drug content (\%) & In vitro drug release (\%) \\
\hline 0 & $97.05 \pm 0.19$ & $95.72 \pm 0.30$ & $96.87 \pm 0.01$ & $95.32 \pm 0.01$ \\
\hline 30 & $96.81 \pm 0.01$ & $95.52 \pm 0.005$ & $96.65 \pm 0.01$ & $95.11 \pm 0.01$ \\
\hline 60 & $96.62 \pm 0.005$ & $95.10 \pm 0.005$ & $96.42 \pm 0.01$ & $94.80 \pm 0.005$ \\
\hline 90 & $96.45 \pm 0.005$ & $94.87 \pm 0.005$ & $96.17 \pm 0.01$ & $94.65 \pm 0.01$ \\
\hline
\end{tabular}

All data are given in mean $\pm S D, n=3$

\section{CONCLUSION}

The results of the study indicated that Amphotericin B proniosomal gel containing lecithin, cholesterol, and surfactant Span and Tween formulations were prepared successfully using the coacervationphase separation method. The F2 formulation showed the highest efficiency. The proniosomal gel formulations were evaluated for their entrapment efficiency, drug content, UV-visible spectroscopy, viscosity, vesicle size and shape with SEM, and the results were found to be within the acceptable range. The study found that F2 has antifungal activity after $48 \mathrm{~h}$, indicating that the developed proniosomal gel was more effective than the control. The results showed that F2 containing span 60 is the most appropriate surfactant for the formation of proniosomes. In vitro release studies proved that the proniosomal gel contains Amp B, which is considered to be a successful topical drug delivery system and provides a sustained release of the encapsulated drug. In vitro release studies showed satisfactory results, and the permeation studies showed good control release for a prolonged period of time. Permeation studies showed the highest permeation of proniosomal gel formulation F2, and in vitro goat skin permeation studies proved that a good amount of drug is permeated and has good stability characteristics. The study showed that the proniosomal gel formulation was quite stable at room temperature and accelerated temperature as well. All the results suggest that Amp B proniosomal gel formulations may be used topically for cutaneous leishmaniasis (CL) treatment.

\section{ACKNOWLEDGMENT}

The authors are thankful to Piramal Pvt. Ltd. for providing Amphotericin B drug as a gift sample for this research work. The authors also thank H. K. College of Pharmacy, Mumbai, Maharashtra, India, for providing the required facilities to carry out this research work.

\section{FUNDING}

No funding was provided for this study.

\section{AUTHORS CONTRIBUTIONS}

The literature search, manuscript framing, preparation, design and drafting the article were done by Reesha Baig. Reviewing it critically for important intellectual content and final editing of the manuscript were done by Dr. Mohd Wais.

\section{CONFLICT OF INTERESTS}

The authors have declared no conflicts of interest.

\section{REFERENCES}

1. Shirsand SB, Kumar GR, Keshavshetti GG, Bushetti SS, Swamy PV. Formulation and evaluation of clotrimazole niosomal gel for topical application. RGUHS J Pharm Sci. 2015;5(1):32-8. doi: 10.5530/rjps.2015.1.4. 
2. Allam AN, Gamal SS, Naggar VF. Formulation and evaluation of acyclovir niosomes for ophthalmic use. Asian J Pharm Bio Res. 2011;1:28-40.

3. Khatoon M, Shah KU, Din FU, Shah SU, Rehman AU, Dilawar N, Khan AN. Proniosomes derived niosomes: Recent advancements in drug delivery and targeting. Drug Delivery 2017;24:56-69.

4. Weiner AL. Liposomes for protein delivery: selecting manufacture and development processes. Immuno Methods. 1994;4(3):201-9. doi: 10.1006/immu.1994.1021, PMID 7820450.

5. Kumar GP, Rajeshwarrao P. Nonionic surfactant vesicular systems for effective drug delivery- an overview. Acta Pharm Sin B. 2011;1(4):208-19. doi: 10.1016/j.apsb.2011.09.002.

6. Lawrence MJ, Chauhan S, Lawrence SM, Barlow DJ. The formation, characterization and stability of non-ionic surfactant vesicles. STP Pharm Sci. 1996;1:49-60.

7. Rawat AS, Kumar MS, Khurana B, Mahadevan N. Proniosomal gel: a novel topical delivery system. Int J Recent Adv Pharm Res. 2011;3:1-10.

8. Berenguer D, Alcover MM, Sessa M, Halbaut L, Guillen C, BoixMontanes A, Fisa R, Calpena Campmany AC, Riera C, Sosa L. Topical amphotericin B semisolid dosage form for cutaneous leishmaniasis: physicochemical characterization, ex vivo skin permeation and biological activity. Pharmaceutics. 2020;12(2):116. doi: 10.3390/pharmaceutics12020149, PMID 32059430.

9. Cohen BE. The role of signaling via aqueous pore formation in resistance responses to amphotericin b. Antimicrob Agents Chemother. 2016;60(9):5122-9. doi: 10.1128/AAC.00878-16, PMID 27381391.

10. de Carvalho RF, Ribeiro IF, Miranda Vilela AL, de Souza Filho J, Martins OP, Cintra e Silva Dde 0, et al. Leishmanicidal activity of amphotericin B encapsulated in PLGA-DMSA nanoparticles to treat cutaneous leishmaniasis in C57BL/6 mice. Exp Parasitol. 2013;135(2):217-22. doi: 10.1016/j.exppara.2013.07.008, PMID 23891944.

11. Torrado JJ, Espada R, Ballesteros MP, Torrado Santiago S. Amphotericin B formulations and drug targeting. J Pharm Sci. 2008;97(7):2405-25. doi: 10.1002/jps.21179, PMID 17893903.

12. Vardhani S, Niroshi M, Chandrashekar KB. Proniosomal gel-an effective approach for topical and transdermal drug delivery. Int J Res Pharm Sci. 2016;7:179-83.

13. Reddy M, Mutalik S, Rao G. Preparation and evaluation of minoxidil gels for topical application in alopecia. Indian J Pharm Sci. 2006;68(4):432-6. doi: 10.4103/0250-474X.27813.

14. Aboelwafa AA, El-Setouhy DA, Elmeshad AN. Comparative study on the effects of some polyoxyethylene alkyl ether and sorbitan fatty acid ester surfactants on the performance of transdermal carvedilol proniosomal gel using experimental design. AAPS PharmSciTech. 2010;11(4):1591-602. doi: 10.1208/s12249-010-9539-0, PMID 21063815.

15. Rajabalaya R, Leen G, Chellian J, Chakravarthi S, David SR. Tolterodine tartrate proniosomal gel transdermal delivery for overactive bladder. Pharmaceutics. 2016;8(3):1-15. doi: 10.3390/pharmaceutics8030027, PMID 27589789.

16. Shah H, Nair AB, Shah J, Bharadia P, Al-Dhubiab BE. Proniosomal gel for transdermal delivery of lornoxicam: optimization using factorial design and in vivo evaluation in rats. Daru. 2019;27(1):5970. doi: 10.1007/s40199-019-00242-x, PMID 30701460.

17. Rajkumar J, Radha GV, Ganapaty S. Topical drug delivery of gossypin from proniosomal gel formulations: in vitro efficacy against human melanoma cells. Int J Appl Pharm. 2021;13:14452. doi: 10.22159/ijap.2021v13i1.39609.

18. Sailaja AK, Shreya M. Preparation and characterization of naproxen loaded niosomes by ether injection method. Nano Biomed Eng. 2018;10(2):174-80. doi: 10.5101/nbe.v10i2.p174-180.

19. Karki R, Mamatha GC, Subramanya G, Udupa N. Preparation, characterization and tissue disposition of niosomes containing isoniazid. Rasayan J Chem. 2008;1:224-7.

20. Pavithra K, Jeganath S, Iqbal A. Design, Development, and Characterization of Topical gel containing itraconazoleantifungalagent. Asian J Pharm Clin Res. 2018;11:153-8.

21. Rao M, Kadam M, Rao S. Formulation and evaluation of topical formulation for cutaneous tuberculosis. J Drug Deliv Ther. 2018;8:102-16.

22. Sabale V, Kunjwani $H$, Sabale P. Formulation and in vitro evaluation of the topical antiageing preparation of the fruit of
Benincasa hispida. J Ayurveda Integr Med. 2011;2(3):124-8. doi: 10.4103/0975-9476.85550, PMID 22022154.

23. Patil HN, Hardikar SR, Bhosale AV. Formulation development and evaluation of proniosomal gel of carvedilol. Int J Pharm Pharm Sci. 2012;4:191-7.

24. Kumar L, Verma R. In vitro evaluation of topical gel prepared using natural polymer. Int J Drug Delivery. 2010;2(1):58-63. doi: 10.5138/ijdd.2010.0975.0215.02012.

25. Farooqui N, Kar M, Singh RP. Formulation and development of proniosomal gel for transdermal delivery of ketorolac tromethamine. Asian J Pharm. 2016;10:394-400.

26. Gupta V, Trivedi P. Ex vivo localization and permeation of cisplatin from novel topical formulations through excised pig, goat, and mice skin and in vitro characterization for effective management of skin-cited malignancies. Artif Cells Nanomed Biotechnol. 2015;43(6):373-82. 10.3109/21691401.2014.893523, PMID 24628359.

27. Leite MC, Bezerra AP, de Sousa JP, Guerra FQ, Lima Ede 0. Evaluation of antifungal activity and mechanism of action of citral against candida albicans. Evid Based Complement Alternat Med. 2014;2014:378280. doi: 10.1155/2014/378280. PMID 25250053.

28. Gupta A, Prajapati SK, Balamurugan M, Singh M, Bhatia D. Design and development of a proniosomal transdermal drug delivery system for captopril. Trop J Pharm Res. 2007;6(2):687-93. doi: 10.4314/tjpr.v6i2.14647.

29. Das S, Samanta A, Bose A. Design, development and evaluation of fluconazole topical gel. Asian J Pharm Clin Res. 2015;8:132-5.

30. Al-Quadeib BT, Radwan MA, Siller L, Horrocks B, Wright MC. Stealth amphotericin B nanoparticles for oral drug delivery: in vitro optimization. Saudi Pharm J. 2015;23(3):290-302. doi: 10.1016/j.jsps.2014.11.004, PMID 26106277.

31. Kazi KM, Mandal AS, Biswas N, Guha A, Chatterjee S, Behera M, Kuotsu K. Niosome: A future of targeted drug delivery systems. J Adv Pharm Technology and Research. 2010;1(4):374-80. doi: 10.4103/0110-5558.76435, PMID 22247876.

32. Manosroi, Aranya, Wongtrakul P, Manosroi J, Sakai H, Sugawara F, Yuasa M, Abe M. Characterization of vesicles prepared with various non-ionic surfactants mixed with cholesterol. Colloids and Surfaces B: Biointerfaces. 2003;30(1-2):129-38. doi: 10.1016/S0927-7765(03)00080-8.

33. Nayebsadrian M, Varshosaz J, Hassanzadeh F, Sadeghi H, Banitalebi M, Rostami M. Screening the most effective variables on physical properties of folate-targeted dextran/retinoic acid micelles by taguchi design. J Nanomaterials. 2012;2012:1-7. doi: $10.1155 / 2012 / 860691$.

34. Hazel G, et al. Development and evaluation of norfloxacin loaded maltodextrin based proniosomes. Int Res J Pharm. 2012;3:176-9.

35. Ozgüney IS, Karasulu HY, Kantarc G, Sözer S, Güneri T, Ertan G Sarigullu Ozguney I, Yeaim Karasulu H, Kantarci G, Sozer S, Guneri T, Ertan G. Transdermal delivery of diclofenac sodium through rat skin from various formulations. AAPS PharmSciTech. 2006;7(4):88. doi: 10.1208/pt070488, PMID 17233540.

36. Ravi GS, Dubey A, Hebbar S. Development of maltodextrin based proniosomes derived niosomes of ofloxacin. IJPSR. 2019;10:1485-90.

37. Aggarwal A, Saroha K, Nanda S. Formulation, evaluation and comparison of ketorolac tromethamine transdermal gel containing natural and synthetic permeation enhancers. Der Pharm Sin. 2014;5:41-5.

38. Bachhav YG, Patravale VB. Microemulsion based vaginal gel of fluconazole: formulation, in vitro and in vivo evaluation. Int J $\begin{array}{lll}\text { Pharm. 2009;365(1-2):175-9. doi } & \text {. }\end{array}$ 10.1016/j.ijpharm.2008.08.021, PMID 18790032.

39. El- Laithy HM, El-Shaboury KMF. The development of cutina lipogels and gel microemulsion for topical administration of fluconazole. AAPS PharmSciTech. 2002;3(4):E35. doi: 10.1208/pt030435, PMID 12916929.

40. Kasar PM, Kale K, Phadtare DG. Formulation and evaluation of topical antifungal gel containing itraconazole. Int J Curr Pharm Sci. 2018;10(4):71-4. doi: 10.22159/ijcpr.2018v10i4.28470.

41. Choi KC, Bang JY, Kim PI, Kim C, Song CE. Amphotericin Bincorporated polymeric micelles composed of poly(d,l-lactide-coglycolide)/dextran graft copolymer. Int J Pharm 2008;355(12):224-30. doi: 10.1016/j.ijpharm.2007.12.011, PMID 18242900. 
42. Fathalla Fathalla D. In vitro and in vivo evaluation of niosomal gel containing aceclofenac for sustained drug delivery. Int J Pharm Sci Res. 2014;1(1):105. doi: 10.15344/23941502/2014/105.

43. Schmook FP, Meingassner JG, Billich A. Comparison of human skin or epidermis models with human and animal skin in in vitro percutaneous absorption. Int J Pharm.
2001;215(1-2):51-6. doi: 10.1016/s0378-5173(00)006657, PMID 11250091.

44. Helal. Formulation and evaluation of fluconazole topical gel. Int J Pharm Pharm Sci. 2012;4:176-83.

45. Bhatia A, Kumar R, Katare OP. Tamoxifen in topical liposomes: develoment, characterization and in vitro evaluation. J Pharm Pharm Sci. 2004; 7:525-9. 